\title{
Revival of Names of Protozoan Endosymbionts and Proposal of Holospora caryophila nom. nov.
}

\author{
J. R. PREER, JR., AND L. B. PREER \\ Department of Biology, Indiana University, Bloomington, Indiana 47405
}

\begin{abstract}
The purpose of this note is to revive, in accordance with the rules of the International Code of Nomenclature of Bacteria, the names of four genera (Caedibacter, Holospora, Lyticum, and Tectibacter) and seven species $(C$. taeniospiralis, $H$. elegans, $H$. obtusa, $H$. undulata, $L$. flagellatum, $L$. sinuosum, and $T$. vulgaris) of protozoan endosymbionts not included on the recently published Approved Lists of Bacterial Names. The names are being revived for the same organisms to which the names were originally applied. The species previously referred to as "Cytophaga caryophila" is here transferred to the genus Holospora as Holospora caryophila nom. nov.
\end{abstract}

None of the previously validly published names of protozoan endosymbionts was included on the Approved Lists of Bacterial Names (8) or has been validly published since 1 January 1980; consequently, they do not have standing in bacterial nomenclature. The purpose of this paper is to effect the revival of the generic and species names listed in Table 1 . All of these names are to be regarded as nomina revicta. The validation of the names of additional protozoan

TABLE 1. List of bacterial names here revived and thereby accorded valid-publication status

\begin{tabular}{|c|c|c|c|c|c|}
\hline \multirow[b]{2}{*}{ Revived name } & \multirow{2}{*}{$\begin{array}{c}\text { Originally } \\
\text { proposed as: }\end{array}$} & \multirow{2}{*}{$\begin{array}{l}\text { Authors of } \\
\text { original } \\
\text { publication }\end{array}$} & \multicolumn{2}{|c|}{ Literature citation to: } & \multirow[b]{2}{*}{ Nomenclatural type ${ }^{a}$} \\
\hline & & & $\begin{array}{c}\text { Original } \\
\text { publication }\end{array}$ & $\begin{array}{c}\text { Description } \\
\text { of taxon }\end{array}$ & \\
\hline
\end{tabular}

Caedibacter

(Caedobacter

[sic])

C. taeniospiralis

Lyticum

L. flagellatum

L. sinuosum

Tectibacter

(Tectobacter [sic])

T. vulgaris

Holospora

H. obtusa

$H$. undulata

H. elegans

\section{New genus}

New species

New genus

New species

New species

New genus

New species

New genus

New species

New species

New species
Preer et al.

Preer et al.

Preer et al.

Preer et al.

Preer et al.

Preer et al. Preer et al.

Hafkine

Hafkine

Hafkine

Hafkine

6
6
6
6
6
6
6
3
3
3
3

C. taeniospiralis Preer and Preer Strain 51 (= ATCC 30632)

L. flagellatum Preer and Preer

Strain 299 (= ATCC 30700)

Strain 114 (= ATCC 30696)

T. vulgaris Preer and Preer

Strain 225 (= ATCC 30697)

$H$. elegans Preer and Preer

Strain C103

Strain C204

Strain C101

${ }^{a}$ ATCC, American Type Culture Collection, Rockville, Md. The accession numbers refer to protozoan strains carrying the endosymbionts.

TABLE 2. Differentiation of the genera of the endosymbionts of ciliates

\begin{tabular}{lcccc}
\hline \multicolumn{1}{c}{ Character } & Holospora & Caedibacter & $\begin{array}{c}\text { "Pseudo- } \\
\text { caedibacter"a }\end{array}$ & Lyticum \\
\hline Found in nuclei & + & $\ldots . b$ & - & - \\
Contain R bodies & - & + & - & - \\
Hosts are killers or mate killers & - & $+c$ & - \\
Contain a thick cell wall & - & - & - & - \\
Flagellated & - & - & - & + \\
Infective & + & - & - & - \\
\hline
\end{tabular}

${ }^{a}$ This name is being validated by Quackenbush (7).

${ }^{b}$ One strain of Caedibacter is found in the macronucleus; the others are cytoplasmic.

${ }^{c}$ Some hosts are killers, some are mate killers, and some are nonkillers. 
TABLE 3. Characteristics differentiating species of the genus Holospora

\begin{tabular}{lcccc}
\hline \multicolumn{1}{c}{ Characteristic } & $\begin{array}{c}\text { H. undulata } \\
\text { omega }\end{array}$ & $\begin{array}{c}\text { H. obtusa } \\
\text { iota }\end{array}$ & $\begin{array}{c}\text { H. elegans } \\
\begin{array}{c}\text { H. caryophila } \\
\text { alpha }\end{array}\end{array}$ \\
\hline $\begin{array}{l}\text { Length of infective form } \\
5-6 \mu \mathrm{m}\end{array}$ & - & - & - & + \\
$7-20 \mu \mathrm{m}$ & + & + & + & - \\
$\begin{array}{l}\text { Shape of infective form } \\
\text { Spiral, tapered ends }\end{array}$ & + & - & - & + \\
$\begin{array}{l}\text { Rod, rounded ends } \\
\text { Thin rods, tapered ends }\end{array}$ & - & + & - & - \\
Habitat & - & - & + & - \\
Micronucleus & + & + & - & + \\
Macronucleus & - & - & + \\
\hline
\end{tabular}

endosymbionts is being effected by Quackenbush (7).

The characteristics useful in distinguishing between the described genera of the endosymbionts of protozoa are given in Table 2 .

The characteristics distinguishing the species of Holospora are given in Table 3 . The study of new collections of holosporas $(1,2,4,5)$ now makes it clear that in structure, infectivity, and habitat the species originally referred to as " $\mathrm{Cy}$ tophaga caryophila" (6) is very close to the other species of Holospora. For this reason, we regard this organism as a member of the genus Holospora, and for it we propose the name Holospora caryophila nom. nov. The type strain of $H$. caryophila is carried in strain 562 of Paramecium biaurelia (= ATCC 30694).

\section{LITERATURE CITED}

1. Görtz, H.-D. 1980. Nucleus-specific symbionts in Paramecium caudatum, p. 381-392. In W. Schwemmler and
H. E. A. Schenk (ed.), Endosymbiosis and cell biology, vol. 1. Walter de Gruyter \& Co., Berlin.

2. Görtz, H.-D., and J. Dieckmann. 1980. Life cycle and infectivity of Holospora elegans Haffkine, a micronucleus-specific symbiont of Paramecium caudatum (Ehrenberg). Protistologica 16:591-603.

3. Hafkine, M. M.-W. 1890. Maladies infectieuses des paramécies. Ann. Inst. Pasteur Paris 4:148-162.

4. Ossipov, D. V., B. V. Gromov, and K. A. Mamkaeva. 1973. Electron microscope examination of omega-particles (bacterial symbionts of the micronucleus) and nucleolar apparatus of Paramecium caudatum clone M1-48. Tsitologiya 15:97-103.

5. Ossipov, D. V., and S. A. Podlipaev. 1977. Electron microscope examination of early stages of infection of Paramecium caudatum by bacterial symbionts of the macronucleus (iota-bacteria). Acta Protozool. 16:289-308.

6. Preer, J. R., Jr., L. B. Preer, and A. Jurand. 1974. Kappa and other endosymbionts in Paramecium aurelia. Bacteriol. Rev. 38:113-163.

7. Quackenbush, R. L. 1982. In Validation of the publication of new names and combinations previously effectively published outside the IJSB. List no. 9. Int. J. Syst. Bacteriol., in press.

8. Skerman, V.B. D., V. McGowan, and P. H. A. Sneath (ed.). 1980. Approved lists of bacterial names. Int. J. Syst. Bacteriol. 30:225-420. 